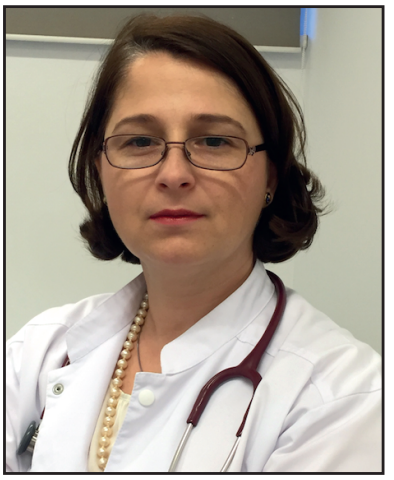

Camelia C. DIACONU凶

International Secretary General of the Balkan Medical Union President of the Romanian National Section

Secrétaire Général International de l'Union Médicale Balkanique Présidente de la Section Nationale Roumaine

\section{THROMBOEMBOLISM IN PATIENTS WITH COVID-19}

The clinical data obtained during the pandemic of coronavirus disease 2019 (COVID-19) indicated that this is a disease associated with an increased risk of thrombosis. Thromboembolic events in patients with COVID-19 lead to a worse clinical evolution and a poor prognosis. Some studies analyzed the prevalence and risk factors for thrombotic complications in patients with COVID-19. An observational study on 3,334 patients admitted for COVID-19 has found that $16 \%$ of patients had a thrombotic complication during hospitalization ${ }^{1} .11 .1 \%$ of these cases had an arterial thrombosis, $8.9 \%$ had myocardial infarction, $1.6 \%$ ischemic stroke and $1 \%$ systemic arterial thrombosis. ${ }^{1}$ Venous thromboembolism was encountered in $6.2 \%$ of patients ${ }^{1}$. Older age, man sex, personal history of ischemic heart disease, and increased D-dimers were all risk factors for thrombosis in this study ${ }^{1}$. Almost one third of patients admitted in the intensive care unit presented thrombotic events and these were associated with a higher risk for in-hospital mortality ${ }^{1}$.

Interestingly, another study on non-hospitalized patients with COVID-19 did not find a significant difference regarding the incidence of venous thromboembolism between these patients and those without COVID-192. The authors analyzed data of 220,588 patients tested for COVID-19 and reported the incidence of thrombosis in out-patients and in-patients, at 30 days. From these patients, 11.8\%

\section{THROMBOEMBOLISME CHEZ LES PATIENTS ATTEINTS DE COVID-19}

Les données cliniques obtenues lors de la pandémie de maladie à coronavirus 2019 (COVID-19) ont indiqué qu'il s'agit d'une maladie associée à un risque accru de thrombose. Les événements thromboemboliques chez les patients atteints de COVID-19 entraînent une évolution clinique plus défavorable et un pronostic sombre. Certaines études ont analysé la prévalence et les facteurs de risque de complications thrombotiques chez les patients atteints de COVID-19. Une étude observationnelle portant sur 3334 patients admis pour COVID-19 a révélé que $16 \%$ des patients présentaient une complication thrombotique pendant l'hospitalisation ${ }^{1} .11,1 \%$ de ces cas avaient une thrombose artérielle, $8,9 \%$ avaient un infarctus du myocarde, $1,6 \%$ un accident vasculaire cérébral ischémique et $1 \%$ une thrombose artérielle systémique ${ }^{1}$. Une thromboembolie veineuse a été rencontrée chez

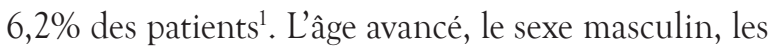
antécédents personnels de cardiopathie ischémique et l'augmentation des D-dimères étaient tous des facteurs de risque de thrombose dans cette étude ${ }^{1}$. Près d'un tiers des patients admis en réanimation présentaient des événements thrombotiques associés à un risque plus élevé de mortalité hospitalière ${ }^{1}$.

Fait intéressant, une autre étude sur des patients non hospitalisés atteints de COVID-19 n'a pas trouvé de différence significative concernant l'incidence de la thromboembolie veineuse entre ces patients et ceux sans COVID-19². Les auteurs ont analysé les 
tested positive for infection with SARS-CoV-2; within 30 days after the positive test, $0.8 \%$ of patients developped venous thromboembolism, compared to $0.5 \%$ of patients with negative tests ${ }^{2}$. However, this study had some limitations regarding the diagnosis of venous thromboembolism and the empirical use of anticoagulants and/or anti-inflammatory drugs. The authors of this study suggested that anticoagulants need to be studied in prospective clinical trials, to evaluate the impact of anticoagulant treatment on outpatients' outcomes.

Regarding the pathophysiology of thrombosis in COVID-19, new data highlight that patients with severe forms of disease have sustained platelet activation, that contribute to the increased risk of thrombosis. Endhotelial injury is another pathophysiological factor that may intervene, by altering hemostasis. Cytokine storm, that appears in patients with severe forms of the disease, will also increase the risk of coagulopathy and thrombosis. The overproduction of inflammatory cytokines, such as tumor necrosis factor (TNF), interleukin-6, interleukin-8 and interleukin-1 is considered the cause of cytokine storm, that may cause multiorgan failure and possibly death ${ }^{3}$. Laboratory tests usually reveal increased D-dimers, thrombocytopenia, elevated fibrin degradation products, and fibrinogen ${ }^{4}$. D-dimer levels are especially increased in patients with critical forms of disease, admitted in intensive care units ${ }^{4}$ and may be a surrogate marker for the disease severity ${ }^{5}$. Because of the clinical consequences of hypercoagulability in patients with COVID-19, hemogram with platelet count, peripheral blood smear, prothrombin time, aPTT, fibrinogen and D-dimers should be monitored in all hospitalized patients with COVID-19. Furthermore, these patients must be investigated and screened for deep venous thrombosis, preferably by duplex scan. Pulmonary thromboembolism, in some studies, has been more frequent than deep venous thrombosis in patients with COVID-19. A study of 1,765 patients diagnosed with COVID-19 reported an incidence of pulmonary embolism of $22 \%$, and even higher in patients admitted in intensive care units ${ }^{6}$. Patients with COVID-19 may also present coagulation abnormalities similar to thrombotic thrombocytopenic purpura, disseminated intravascular coagulation, or hemolytic uremic syndrome.

Thrombotic comlications in COVID-19 have some unique characteristics that must be deeper investigated, for a better management of this disease. données de 220588 patients testés pour COVID-19 et ont rapporté l'incidence de la thrombose chez les patients ambulatoires et hospitalisés, à 30 jours. Parmi ces patients, $11,8 \%$ ont été testés positifs pour l'infection par le SRAS-CoV-2; dans les 30 jours suivant le test positif, $0,8 \%$ des patients ont développé une thromboembolie veineuse, contre $0,5 \%$ des patients avec des tests négatifs ${ }^{2}$. Cependant, cette étude présentait certaines limites concernant le diagnostic de la thromboembolie veineuse et l'utilisation empirique d'anticoagulants et/ou d'anti-inflammatoires. Les auteurs de cette étude ont suggéré que les anticoagulants doivent être étudiés dans des essais cliniques prospectifs, afin d'évaluer l'impact du traitement anticoagulant sur les résultats des patients ambulatoires.

En ce qui concerne la physiopathologie de la thrombose dans COVID-19, de nouvelles données mettent en évidence que les patients atteints de formes sévères de la maladie ont une activation plaquettaire soutenue, ce qui contribue au risque accru de thrombose. La lésion endhoteliale est un autre facteur physiopathologique qui peut intervenir, en altérant l'hémostase. La tempête de cytokines, qui apparaît chez les patients atteints de formes sévères de la maladie, augmentera également le risque de coagulopathie et de thrombose. La surproduction de cytokines inflammatoires, telles que le facteur de nécrose tumorale (TNF), l'interleukine-6, l'interleukine- 8 et l'interleukine-1 est considérée comme la cause d'une tempête de cytokines, qui peut entraîner une défaillance multiviscérale et éventuellement la mort $^{3}$. Les tests de laboratoire révèlent généralement une augmentation des D-dimères, une thrombocytopénie, des produits de dégradation de la fibrine et du fibrinogène élevés ${ }^{4}$. Les taux de $\mathrm{D}$-dimères sont particulièrement augmentés chez les patients atteints de formes critiques de la maladie, admis dans des unités de soins intensifs ${ }^{4}$ et peuvent être un marqueur de substitution de la gravité de la maladie 5 . En raison des conséquences cliniques de l'hypercoagulabilité chez les patients atteints de COVID-19, l'hémogramme avec numération plaquettaire, frottis sanguin périphérique, temps de Quick, aPTT, fibrinogène et $\mathrm{D}$-dimères doit être surveillé chez tous les patients hospitalisés atteints de COVID-19. De plus, ces patients doivent être recherchés et dépistés pour une thrombose veineuse profonde, de préférence par écho-Doppler. La thromboembolie pulmonaire, dans certaines études, a été plus fréquente que la thrombose veineuse profonde chez les patients atteints de COVID-19. Une étude de 1765 patients diagnostiqués avec COVID-19 a rapporté une incidence d'embolie pulmonaire de $22 \%$, et encore plus élevée chez les patients admis dans les unités de soins intensifs ${ }^{6}$. Les patients atteints de COVID-19 peuvent également 
présenter des anomalies de la coagulation similaires au purpura thrombocytopénique thrombotique, à la coagulation intravasculaire disséminée ou au syndrome hémolytique et urémique.

Les complications thrombotiques de COVID-19 ont des caractéristiques uniques qui doivent être étudiées plus en profondeur, pour une meilleure gestion de cette maladie.

"No conflict of interest"

\section{References}

1. Bilaloglu S, Aphinyanaphongs Y, Jones S, et al. Thrombosis in hospitalized patients with COVID-19 in a New York City health system. JAMA. 2020;324:799-801.

2. Roubinian NH, Dusendang JR, Mark DG, et al. Incidence of 30-day venous thromboembolism in adults tested for SARS-CoV-2 infection in an integrated health care system in Northern California. JAMA Intern Med. Published online April 5, 2021. https:// jamanetwork.com/journals/jamainternalmedicine/fullarticle/2778371

3. Meduri GU, Kohler G, Headley S, Tolley E, Stentz F, Postlethwaite A. Inflammatory cytokines in the BAL of patients with ARDS. Persistent elevation over time predicts poor outcome. Chest. 1995;108:1303-14.

4. Huang C, Wang Y, Li X, et al. Clinical features of patients infected with 2019 novel coronavirus in Wuhan, China. Lancet. 2020;395:497-506.

5. Tang N, Li D, Wang X, Sun Z. Abnormal coagulation parameters are associated with poor prognosis in patients with novel coronavirus pneumonia. J Thromb Haemost. 2020; 18:844-847.

6. Al-Ani F, Chehade S, Lazo-Langner A. Thrombosis risk associated with COVID-19 infection a scoping review. Thromb Res. 2020;192:152-160. 